\title{
Formulation of Eco-friendly Management Package Against Seedling Disease Caused by Sclerotium rolfsii of Lentil
}

\author{
Md. Iqbal Faruk*, Md. Monirul Islam, Firoza Khatun \\ Plant Pathology Division, Bangladesh Agricultural Research Institute, Gazipur, Bangladesh \\ Email address: \\ mifaruk2012@yahoo.com (Md. I. Faruk), mifaruk2013@gmail.com (Md. I. Faruk), monirulbari@yahoo.com (Md. M. Islam), \\ firoza.bari@gmail.com (F. Khatun) \\ ${ }^{*}$ Corresponding author
}

To cite this article:

Md. Iqbal Faruk, Md. Monirul Islam, Firoza Khatun. Formulation of Eco-friendly Management Package Against Seedling Disease Caused by Sclerotium rolfsii of Lentil. American Journal of BioScience. Vol. 8, No. 3, 2020, pp. 65-72. doi: 10.11648/j.ajbio.20200803.13

Received: March 3, 2020; Accepted: March 19, 2020; Published: June 8, 2020

\begin{abstract}
The experiments were conducted in the fields of Plant Pathology Division, Bangladesh Agricultural Research Institute, Gazipur during 2014-15, 2015-16 and 2016-17 cropping years to observe the effect of formulated Trichoderma harzianum (Soil amendment with Tricho-compost and seed treatment with $T$. harzianum spore suspension) and organic soil amendment poultry refuse either singly or in combination with seed treatment with fungicide Provax 200 WP against soilborne pathogens, Sclerotium rolfsii of lentil causing seedling disease. The partially decomposed poultry refuse was incorporated in the 2 weeks before seed sowing of lentil where Tricho-composts were incorporated in the soil 7 days before seed sowing. Seeds were treated with Trichoderma spore suspension and Provax $200 \mathrm{WP}$ at the time of seed sowing. From this study it was revealed that soil amendment with Tricho-compost or integration poultry refuse with seed treatment by Provax 200 WP performed as the best treatments in reducing seedling mortality and increasing plant growth and yield of lentil which was significantly differed from the other treatments including control. Seed treatment with chemical fungicide provax showed better performance against the disease also seed treatments with Trichoderma spores suspension and soil amendment with poultry refuse which effect at per. Both of them reduced seedling mortality and increased plant growth and yield of lentil.
\end{abstract}

Keywords: Trichoderma harzianum, Sclerotium rolfsii, Lens Culinaris, Lentil, Seedling Disease

\section{Introduction}

Lentil (Lens culinaris) is the second most important pulse crop in terms of area $(154,000 \mathrm{ha})$ and production $(116,000 \mathrm{t})$, but it is the first consumed and cheap source of protein for human beings and animals in Bangladesh $[1,2]$. It is an integral part of the daily diet as a direct source of protein for human beings in Bangladesh [2]. But the cultivated area and production of lentil is gradually decreasing from the last decades. The average yield of lentil per unit area in Bangladesh is low as compared to that of other lentil growing countries like Syria, Turkey, Canada, USA and Ethiopia [3]. Both biotic and abiotic factors are associated with low yield of lentil in Bangladesh. Among the biotic factors, diseases are considered as the major constraints which attack plants during seedling to maturity stages. Seedling diseases are more destructive and causing 30-40\% yield loss in lentil $[4,5]$. Seedling diseases caused by soil borne pathogens Sclerotium rolsfii and Fusarium oxysporum Schlecht are more destructive pathogens of pulses in almost all legumegrowing countries of the world and under congenial conditions resulting up to $100 \%$ seedling mortality culminating drastic reduction in grain $[5,6]$. There is no effective resistant variety of lentils against this disease. On the other hand management of soil-borne pathogens by chemical fungicides hardly successful in the field and indiscriminate use of chemicals also causes environmental pollution and health hazards [7]. Due to environmental concerns, researchers have focused on finding eco-friendly diseases management alternatives to chemical pesticides for suppression of soil borne plant pathogens [8]. In this context, alternative approaches including crop rotation, use of soil amendment, solarization, bio-fumigation, biological soil disinfestations, grafting, and application of biocontrol agents or organic amendments, such as composts, are of considerable interest among scientists and agricultural producers [9-12]. Numerous studies have shown that biological control offers an environmentally friendly alternative to protect plants from soil- 
borne pathogens $[13,14]$. Various fungal species are used as biological agents that effectively control plant diseases especially soil borne diseases, and about $90 \%$ of such biocontrol agents are different species of Trichoderma genus such as $T$. harzianum, T. virens, T. viride [15]. T. harzianum is commercially used as preventive measure for several soil borne plant pathogenic fungi [16, 17]. For mass production of Trichoderma, many researchers have successfully used cost effective substrates like wheat bran, rice bran, maize bran, sawdust [18]; rice straw, chickpea bran, grass pea bran, rice course powder, black gram bran [19]; cow dung, poultry manure, ground nut shell, black ash, coir waste, spent straw from mushroom bed, talc, vermiculite [20], sewage sludge compost [21]. On the other hand the use of organic amendments such as animal manure, green manure, composts and peats has been proposed, both for conventional and biological systems of agriculture, to improve soil structure and fertility [22-24], and decrease the incidence of disease caused by soil borne pathogens $[25,26]$. Therefore, the present study has been designed to formulate eco-friendly disease management packages by using different approaches viz.: T. harzianum based Tricho-composts, soil amendment with poultry manure or integration of poultry manure and seed treatment with chemical fungicides for the management of seedling disease of lentil caused by soil borne fungal pathogen $S$. rolfsii Sacc.

\section{Materials and Methods}

The effect of bio-control agent T. harhianum and organic soil amendment poultry manure in controlling seedling disease of lentil caused by Sclerotium rolfsii was investigated in the field of plant pathology Division of Bangladesh Agricultural Research Institute at three cropping seasons during 2014-15, 2015-16 and 2016-17. Previously, seventy two isolates of $T$. harzianum were isolated from different location of Bangladesh and their efficacy was tested against different soil borne pathogens including $S$. rolfsii in the laboratory. Few isolates of T. harzianum including TKC-3 were found more vigorous to suppress the soil borne pathogens including $S$. rolfsii.

\subsection{Tricho-compost Preparation}

A pure culture of $T$. harzianum (TKC-3) was grown in potato dextrose agar (PDA) medium which was used to formulate in the substrates containing a mixture of rice bran, wheat bran and mustard oilcake. The formulated $T$. harzianum was used for mass multiplication in two different mixtures of cow dung based compost materials. One of those composts contained cow dung and rice bran and the other contained a mixture of cow dung, rice bran and poultry manure. The formulated $T$. harzianum was added in between two layers of compost materials and kept for 45-50 days maintaining the moisture content approximately $60-70 \%$ for rapid multiplication in the compost materials. Based on compost materials used in composting these composts were designated as Tricho-compost-1 and Tricho-compost-2.

\subsection{Pathogenic Fungal Inocula Preparation}

The pure cultures of the pathogenic fungi S. rolfsii was prepared on potato dextrose agar (PDA) medium. The inoculum of $S$. rolfsii was multiplied on a mixture of wheat bran, khesari bran and mustard oilcake (MOC).

\subsection{Seed Treatment}

The T. harzianum was cultured in potato dextrose agar (PDA) medium and the spores were harvested from 10 days old culture. The seeds of lentil (var. BARI Mashur-5) were treated with the spore suspension of $T$. harzianum maintaining the approximate spore concentration of $1 \times 10^{8} / \mathrm{ml} 6 \mathrm{hrs}$ before seed sowing. After treated the seeds were air dry. Similarly another set of seeds were also treated with seed treating chemical Provax 200 WP @ $2.5 \mathrm{~g} / \mathrm{kg}$ seeds at the time of seed sowing.

\subsection{Field Experiment}

The field trials were conducted in the fields of Plant Pathology Division, BARI, Gazipur during 2014-15, 2015-16 and 2016-17 cropping years. There were seven treatments such as (i) Seed treatment with Provax 200 WP @ $2.5 \mathrm{gkg}^{-1}$ (ii) Seed treatment with Trichoderma spore suspension@ @ 1 $10^{8}$ spore $\mathrm{ml}^{-1}$ (iii) Soil amendment with Tricho-compost-1@3 tha ${ }^{-1}$ (iv) Soil amendment with Tricho-compost-2@3 tha ${ }^{-1}$ (v) Soil amendment with poultry refuse @ 5 tha $^{-1}$ (vi) Seed treatment with Provax 200 WP@ $2.5 \mathrm{gkg}^{-1}+$ Soil amendment with poultry refuse @ 3 tha $^{-1}$ and (vii) Untreated control. The field experiment was laid out in randomized complete block design (RCBD) with 3 replications. The unit plot size was $3.5 \mathrm{~m} \times 3 \mathrm{~m}$. The field soil was inoculated with $S$. rolfsii colonized substrate consisting of khesari bran, wheat bran and mustard oilcake @ $100 \mathrm{~g} / \mathrm{m}^{2}$ of soil and allowed the pathogen establishment in the soil for 7 days. Then the inoculated soil was again treated with the Tricho-composts and kept for 5 days for Trichoderma establishment. On the other hand the requisite quantity of partially decomposed poultry manure were incorporated in the soil 2 weeks before seed sowing and allowed to decompose properly. The seeds of lentil var. BARI Mashur-5 were sown in the experimental plots maintaining row to row distance of $40 \mathrm{~cm}$. Proper intercultural operations were done for better growth of lentil in the field. No plant protecting chemicals (insecticides or fungicides) were applied in the field.

\subsection{Determination of Seedling Disease}

The experimental plots were inspected routinely to observe the foot and root rot of lentil disease initiation in the field. In case of any complexity to identify the disease, the infected plants were collected from the field and brought to the laboratory for further study. From the infected plants, the pathogens were isolated following tissue planting methods [27] (Baxter et al., 1999). After incubation, the fungi that grew over potato dextrose agar (PDA) were purified by the hyphal tip culture method. The isolated fungus was identified as $S$. rolfsii according to reference mycology books and manuals [28 and 29]. The pure cultures of the fungi were preserved in PDA slants at $4^{\circ} \mathrm{C}$ in the refrigerator as stock culture for future use. 


\subsection{Data Collection and Analysis}

Data on different parameters viz. germination, postemergence seedling mortality due to seedling disease, shoot length, root length, shoot weight, root weight, yield of lentil were taken. Data were analysis by using MSTATC program following ANOVA. Treatment means were computed using least significant difference (LSD) test.

\section{Results}

\subsection{Seedling Emergence and Pre-emergence Mortality}

In every year, soil amendment with Tricho-composts, poultry refuse, seed treatment with Tricho-inocula and Provax 200 WP and integration of poultry refuse with Provax 200 WP gave significantly higher seedling emergence of lentil compared to control (Table 1). In the $1^{\text {st }}$ year, seedling emergence varied from 92.33-95.67\% among the treatments where control gave comparatively lower $74.67 \%$ seedling emergence of lentil (Table 1). Similarly, soil amendment with Tricho-composts, poultry refuse, seed treatment with Tricho-inocula, Provax 200 WP and integration poultry refuse with Provax 200 WP gave higher seedling emergence in the $2^{\text {nd }}$ year and $3^{\text {rd }}$ year trials ranged from $76.67-83.33 \%$ and 77.33 to $83.33 \%$, respectively and the lowest seedling emergence of $48.33 \%$ in $2^{\text {nd }}$ year and $49.33 \%$ in $3^{\text {rd }}$ year was recorded in control treatment.

On the contrary, soil and seed treatment with the Trichoderma biocontrol agents, organic soil amendment poultry refuse and chemical fungicide Provax caused significant reduction in preemergence seedling mortality of lentil compared to control. The range of pre-emergence seedling mortality was $4.33-7.67 \%$ in the $1^{\text {st }}$ year, $16.67-23.33 \%$ in second year and $16.67-22.67 \%$ in third year. The corresponding mortality under control was 25.33 , 51.67 and $50.67 \%$ in first year, second year and third year, respectively (Table 1 ).

Table 1. Effect of Tricho-composts with T. harzianum and poultry refuse on the seedling emergence of lentil during three consecutive years.

\begin{tabular}{|c|c|c|c|c|c|c|}
\hline \multirow{2}{*}{ Treatment } & \multicolumn{3}{|c|}{ Average seedling emergence (\%) } & \multicolumn{3}{|c|}{ Pre-emergence seedling mortality (\%) } \\
\hline & 2014-15 & 2015-16 & 2016-17 & 2014-15 & 2015-16 & 2016-17 \\
\hline Seed treatment with Provax & $95.00(78.10 \mathrm{a})$ & 78.33 a $(62.48)$ & $79.00 \mathrm{ab}(62.77)$ & 5.00 & 21.67 & 21.00 \\
\hline Seed treatment with Trichoderma inocula & $95.00(78.10 \mathrm{a})$ & $77.00 \mathrm{a}(61.37)$ & $78.00 \mathrm{~b}(62.04)$ & 5.00 & 23.00 & 22.00 \\
\hline Soil amendments with Tricho-compost-1 & $95.67(82.96 \mathrm{a})$ & $79.00 \mathrm{a}(62.90)$ & $81.33 \mathrm{ab}(64.45)$ & 4.33 & 21.00 & 18.67 \\
\hline Soil amendments with Tricho-compost-2 & $95.67(78.76 a)$ & 77.00 a $(61.37)$ & $80.67 \mathrm{ab}(63.96)$ & 4.33 & 23.00 & 19.33 \\
\hline Soil amendments with poultry refuse & $92.33(77.54 \mathrm{a})$ & 76.67 a $(61.15)$ & $77.33 \mathrm{~b}(61.58)$ & 7.67 & 23.33 & 22.67 \\
\hline Poultry refuse + Seed treatment with Provax & $96.00(79.35 \mathrm{a})$ & 83.33 a $(65.95)$ & 83.33 a $(65.91)$ & 4.00 & 16.67 & 16.67 \\
\hline LSD & 15.61 & 7.589 & 2.945 & - & - & - \\
\hline
\end{tabular}

Values in a column having same letter did not differ significantly $(\mathrm{P}=0.05)$ by LSD; values within the parenthesis is the Arcsin Transformed value.

\subsection{Post-emergence Mortality}

Post-emergence seedling mortality due to foot and root rot of lentil was sharply reduced by soil amendment with Trichocomposts, poultry refuse, seed treatment with Tricho-inocula and Provax $200 \mathrm{WP}$ and the integration poultry refuse and Provax 200 WP during three cropping years (Table 2). The highest seedling mortality $25.33 \%, 45.00 \%$ and $43.67 \%$ in the first year, second year and third year, respectively was recorded in the untreated control plot. Soil amendment with Tricho-composts, poultry refuse, integration of poultry refuse + seed treatment with Provax 200 WP and seed treatment with Tricho-inocula and Provax 200 WP gave lower seedling mortality range from $2.67-11.00 \%$ in the first year, 12.33 $17.67 \%$ in the second year and $10.00-19.33 \%$ in the third year. The reduction of seedling mortality was from 56.57 $89.46 \%$ in first year, $60.73-72.60 \%$ in second year and $55.74-$ $77.10 \%$ in third years due to various treatments as compared to untreated control. Integration of poultry refuse + Provax 200 WP gave the highest reduction of seedling mortality by $89.46 \%$ in the $1^{\text {st }}$ year, $72.60 \%$ in the $2^{\text {nd }}$ year and $77.10 \%$ in the $3^{\text {rd }}$ year followed by soil amendment with Trichocompost-2, Tricho-compost-1, poultry refuse and seed treatment with Provax 200 WP. Seed treatment with Trichoinocula was the least effective treatment in reduction of seedling mortality compared to other treatments.

Table 2. Effect of Tricho-composts with T. harzianum and poultry refuse on the reduction of seedling disease of lentil during three consecutive years.

\begin{tabular}{|c|c|c|c|c|c|c|}
\hline \multirow[t]{2}{*}{ Treatment } & \multicolumn{3}{|c|}{$\begin{array}{l}\text { Average post-emergence seedling mortality due to foot } \\
\text { and root rot disease }(\%)\end{array}$} & \multicolumn{3}{|c|}{$\begin{array}{l}\text { Reduction of post-emergence seedling } \\
\text { mortality than control }(\%)\end{array}$} \\
\hline & 2014-15 & $2015-16$ & 2016-17 & 2014-15 & 2015-16 & 2016-17 \\
\hline Seed treatment with Provax & $6.33(14.57 \mathrm{c})$ & $15.00 \mathrm{~b}(22.60)$ & $13.33 \mathrm{~cd}(21.39)$ & 75.01 & 66.67 & 69.48 \\
\hline Seed treatment with Trichoderma inocula & $11.00(19.36 b)$ & $17.67 \mathrm{~b}(24.82)$ & $19.33 \mathrm{~b}(26.06)$ & 56.57 & 60.73 & 55.74 \\
\hline Soil amendments with Tricho-compost-1 & $3.67(10.76 \mathrm{~d})$ & $16.67 \mathrm{~b}(23.96)$ & $14.67 \mathrm{bcd}(22.48)$ & 85.51 & 62.96 & 66.41 \\
\hline Soil amendments with Tricho-compost-2 & $2.67(9.27 \mathrm{~d})$ & $12.67 \mathrm{~b}(20.67)$ & $12.67 \mathrm{~cd}(20.84)$ & 89.46 & 71.84 & 70.99 \\
\hline Soil amendments with poultry refuse & $6.00(14.39 \mathrm{c})$ & $16.33 \mathrm{~b}(23.68)$ & $16.67 \mathrm{bc}(23.87)$ & 76.31 & 63.71 & 61.83 \\
\hline Control & $25.33(30.21 \mathrm{a})$ & $45.00 \mathrm{a}(42.12)$ & $43.67 \mathrm{a}(41.35)$ & - & - & - \\
\hline LSD & 2.56 & 6.354 & 3.979 & - & - & - \\
\hline
\end{tabular}

Values in a column having same letter did not differ significantly $(\mathrm{P}=0.05)$ by LSD; values within the parenthesis is the Arcsin Transformed value. 


\subsection{Shoot Growth}

Shoot growth such as shoot length and shoot weight of chickpea were significantly enhanced by different treatments in all the years (Table 3). The lowest shoot length $15.67 \mathrm{~cm}, 26.50 \mathrm{~cm}$ and $28.67 \mathrm{~cm}$ in the first year, second year and third year, respectively was recorded under control plot. In first year, integration of poultry refuse + seed treatment with Provax and soil amendment with Tricho-compost-2 gave the higher shoot length of $25.00 \mathrm{~cm}$ and $24.93 \mathrm{~cm}$, respectively followed by soil amendment with Tricho-compost-1, poultry refuse and seed treatment with Provax 200 WP and Tricho-inocula. In the second year, integration of poultry refuse + seed treatment with Provax and soil amendment with Tricho-compost- 1 and Trichocompost-2 gave the higher shoot length of $36.40 \mathrm{~cm}, 35.73$ $\mathrm{cm}$ and $35.15 \mathrm{~cm}$, respectively followed by seed treatment with Provax 200 WP, soil amendment with poultry refuse and seed treatment with Trichoderma inocula where the shoot length was $32.67 \mathrm{~cm}, 32.27 \mathrm{~cm}$ and $31.60 \mathrm{~cm}$, respectively (Table 3). During third year trial, integration of poultry refuse + seed treatment with Provax gave the highest shoot length of $33.43 \mathrm{~cm}$ followed by soil amendment with Tricho-compost-2, Tricho-compost-1 and poultry refuse. Seed treatment with Trichoderma inocula was least effective treatment followed by seed treatment with Provax 200 WP. The lowest shoot height was recorded from untreated control in all the years.

Under control treatment the shoot weight of lentil was 1.63 , 8.62 and 1.70 gplant $^{-1}$ in first, second and third year, respectively. Soil amendment and seed treatment with poultry refuse, Tricho-composts, Trichoderma inocula and chemical fungicide Provax increased the parameter to 2.203.27, 11.67-16.33 and 2.10-3.28 gplant ${ }^{-1}$ in first, second and third year, respectively. Every year, the shoot weight of lentil was significantly increased due to different treatments compared to control. Among the treatments integration of poultry refuse + Provax $200 \mathrm{WP}$ and soil amendment with Tricho-compost-2 gave the highest shoot weight in all the years followed by soil amendment Tricho-compost-1, poultry refuse alone and seed treatment with Provax 200 WP. The lowest shoot weight was recorded from control treatment in all the years (Table 3 ).

Table 3. Effect of Tricho-composts with T. harzianum and poultry refuse on the shoot growth of lentil during three consecutive years.

\begin{tabular}{|c|c|c|c|c|c|c|}
\hline \multirow{2}{*}{ Treatment } & \multicolumn{2}{|c|}{ Average shoot length (cm) } & \multicolumn{4}{|c|}{ Average shoot weight $\left(\right.$ gplant $\left.^{-1}\right)$} \\
\hline & 2014-15 & $2015-16$ & 2016-17 & 2014-15 & 2015-16 & 2016-17 \\
\hline Seed treatment with Provax & $20.67 \mathrm{~b}$ & $32.67 \mathrm{~b}$ & $26.10 \mathrm{~d}$ & $2.33 \mathrm{bc}$ & $12.67 \mathrm{~b}$ & $2.23 \mathrm{c}$ \\
\hline Seed treatment with Trichoderma inocula & $20.67 \mathrm{~b}$ & $31.60 \mathrm{~b}$ & $24.23 \mathrm{e}$ & $2.20 \mathrm{~cd}$ & $11.67 \mathrm{c}$ & $2.10 \mathrm{c}$ \\
\hline Soil amendments with Tricho-compost-1 & $21.87 \mathrm{ab}$ & $35.73 \mathrm{a}$ & $29.63 \mathrm{c}$ & $2.47 \mathrm{bc}$ & $15.25 \mathrm{a}$ & $2.65 \mathrm{~b}$ \\
\hline Soil amendments with Tricho-compost-2 & $24.93 \mathrm{a}$ & $35.15 \mathrm{a}$ & $31.81 \mathrm{~b}$ & $2.93 \mathrm{ab}$ & $15.67 \mathrm{a}$ & $3.10 \mathrm{a}$ \\
\hline Soil amendments with poultry refuse & $21.07 \mathrm{~b}$ & $32.27 \mathrm{~b}$ & $28.63 \mathrm{c}$ & $2.47 \mathrm{bc}$ & $12.67 \mathrm{~b}$ & $2.73 \mathrm{~b}$ \\
\hline Poultry refuse + Seed treatment with Provax & $25.00 \mathrm{a}$ & $36.40 \mathrm{a}$ & $33.43 \mathrm{a}$ & $3.27 \mathrm{a}$ & $16.33 \mathrm{a}$ & $3.28 \mathrm{a}$ \\
\hline LSD & 3.058 & 3.639 & 1.505 & 0.59 & 1.913 & 0.308 \\
\hline
\end{tabular}

Values in a column having same letter did not differ significantly $(\mathrm{P}=0.05)$ by LSD.

\subsection{Root Growth}

The root length of lentil was significantly lower in the control by $6.40 \mathrm{~cm}, 6.10 \mathrm{~cm}$ and $7.23 \mathrm{~cm}$ in the $1^{\text {st }}$ year, $2^{\text {nd }}$ year and $3^{\text {rd }}$ year, respectively compared to integration of poultry refuse + Provax $200 \mathrm{WP}$, soil amendments with poultry refuse, Tricho-composts and Provax treatments. The root length of lentil under different treatments was increased significantly compared to control which was ranged from
$7.67-10.13 \mathrm{~cm}, 9.17-12.10 \mathrm{~cm}$ and $8.20-11.70 \mathrm{~cm}$ in the $1^{\text {st }}$ year, $2^{\text {nd }}$ year and $3^{\text {rd }}$ year, respectively (Table 4$)$. In case of root weight significantly higher root weight range from 530$600,683-927$ and 680-980 mgplant $^{-1}$ in the $1^{\text {st }}$ year, $2^{\text {nd }}$ year and $3^{\text {rd }}$ year, respectively was recorded in the different treatments. The lowest root weight 420,453 and 520 mgplant ${ }^{-1}$ in the $1^{\text {st }}$ year, $2^{\text {nd }}$ year and $3^{\text {rd }}$ year, respectively was recorded from control (Table 4).

Table 4. Effect of Tricho-composts with T. harzianum and poultry refuse on the root growth of lentil during three consecutive years.

\begin{tabular}{|c|c|c|c|c|c|c|}
\hline \multirow{2}{*}{ Treatment } & \multicolumn{2}{|c|}{ Average root length (cm) } & \multicolumn{4}{|c|}{ Average root weight $\left(\right.$ mgplant $\left.^{-1}\right)$} \\
\hline & 2014-15 & 2015-16 & 2016-17 & 2014-15 & 2015-16 & 2016-17 \\
\hline Seed treatment with Provax & $7.67 \mathrm{~cd}$ & $9.17 \mathrm{~b}$ & $8.83 \mathrm{de}$ & $530 \mathrm{a}$ & $683 \mathrm{~b}$ & $700 \mathrm{~d}$ \\
\hline Seed treatment with Trichoderma inocula & $8.60 \mathrm{bc}$ & $9.60 \mathrm{~b}$ & $8.20 \mathrm{e}$ & $540 \mathrm{a}$ & $750 \mathrm{~b}$ & $680 \mathrm{~d}$ \\
\hline Soil amendments with Tricho-compost-1 & $9.20 \mathrm{ab}$ & $10.22 \mathrm{~b}$ & $9.87 \mathrm{bc}$ & $600 \mathrm{a}$ & $880 \mathrm{a}$ & $870 \mathrm{bc}$ \\
\hline Soil amendments with Tricho-compost-2 & $10.13 \mathrm{a}$ & $11.53 \mathrm{a}$ & $10.37 \mathrm{~b}$ & $570 \mathrm{a}$ & $940 \mathrm{a}$ & $910 \mathrm{ab}$ \\
\hline Soil amendments with poultry refuse & $9.13 \mathrm{ab}$ & $10.20 \mathrm{~b}$ & $9.37 \mathrm{~cd}$ & $570 \mathrm{a}$ & $687 \mathrm{~b}$ & $820 \mathrm{c}$ \\
\hline Poultry refuse + Seed treatment with Provax & $10.13 \mathrm{a}$ & $12.10 \mathrm{a}$ & $11.70 \mathrm{a}$ & $600 \mathrm{a}$ & 927 a & $980 \mathrm{a}$ \\
\hline LSD & 1.355 & 0.718 & 0.813 & 0.079 & 0.128 & 0.079 \\
\hline
\end{tabular}

Values in a column having same letter did not differ significantly $(\mathrm{P}=0.05)$ by LSD. 


\subsection{Yield of Lentil}

Every year, the yield of lentil was significantly increased by the integration of poultry refuse + Provax $200 \mathrm{WP}$, soil amendment Tricho-composts, poultry refuse, seed treatment with Provax $200 \mathrm{WP}$ and Trichoderma inocula compared to control (Table 5). The lowest yield of lentil was recorded under control by 946, 952 and $1008 \mathrm{kgha}^{-1}$ in the first year, second year and third year, respectively (Table 5). The yield was increased significantly ranging from 1238-1670, 12851689 and $1308-1705 \mathrm{kgha}^{-1}$ in the first year, second year and third year, respectively due to different treatments. Among the treatments, soil amendment with poultry + seed treatment with Provax 200 gave the maximu yield by 1670, 1689 and 1705 $\mathrm{kgha}^{-1}$ in the $1^{\text {st }}$ year, $2^{\text {nd }}$ year and $3^{\text {rd }}$ year, respectively followed by soil amendment with Tricho-compost-2, Trichocompost-1, soil amendment with poultry refuse and seed treatment with Provax 200 where the yield was 1663, 1422, 1365 and $1368 \mathrm{kgha}^{-1}$ in the $1^{\text {st }}$ year, 1676, 1628, 1492 and
$1418 \mathrm{kgha}^{-1}$ in the $2^{\text {nd }}$ year and $1605,1508,1524$ and 1492 $\mathrm{kgha}^{-1}$ in the $3^{\text {rd }}$ year, respectively. Seed treatment with Trichoderma inocula gave lower yield by 1238, 1285 and 1308 $\mathrm{kgha}^{-1}$ in the first year, second year and third year, respectively compared to other treatments but significantly higher than control. Integration of poultry refuse + Provax 200 gave the maximum $43.35 \%, 43.64 \%$ and $40.88 \%$ higher yield in the $1^{\text {st }}$ year, $2^{\text {nd }}$ year and $3^{\text {rd }}$ year, respectively compared to control followed by Tricho-compost-2, Tricho-compost-1, soil amendment with poultry refuse and seed treatment with Provax 200 WP where the yield was $43.11 \%, 33.47 \%, 30.70 \%$ and $30.85 \%$ higher in the first year, $43.20 \%, 41.52 \%, 36.19 \%$ and $32.86 \%$ higher in the $2^{\text {nd }}$ year, $37.20 \%, 33.16 \%, 33.85 \%$ and $32.44 \%$ higher in the $3^{\text {rd }}$ year, respectively compared to control. But seed treatment with Trichoderma inocula gave only $23.58 \%, 25.91 \%$ and $22.94 \%$ higher yield in the $1^{\text {st }}$ year, $2^{\text {nd }}$ year and $3^{\text {rd }}$ year, respectively compared to control.

Table 5. Effect of Tricho-composts with T. harzianum and poultry refuse on the yield of lentil during three consecutive years.

\begin{tabular}{|c|c|c|c|c|c|c|}
\hline \multirow{2}{*}{ Treatment } & \multicolumn{3}{|c|}{ Yield $\left(\mathrm{kgha}^{-1}\right)$} & \multicolumn{3}{|c|}{ Yield higher than control (\%) } \\
\hline & 2014-15 & $2015-16$ & 2016-17 & 2014-15 & $2015-16$ & 2016-17 \\
\hline Seed treatment with Provax & $1368 \mathrm{~b}$ & $1418 \mathrm{~b}$ & 1492 b & 30.85 & 32.86 & 32.44 \\
\hline Seed treatment with Trichoderma inocula & $1238 \mathrm{~b}$ & $1285 \mathrm{c}$ & $1308 \mathrm{c}$ & 23.58 & 25.91 & 22.94 \\
\hline Soil amendments with Tricho-compost-1 & $1422 \mathrm{~b}$ & $1628 \mathrm{a}$ & $1508 \mathrm{~b}$ & 33.47 & 41.52 & 33.16 \\
\hline Soil amendments with Tricho-compost-2 & $1670 \mathrm{a}$ & 1689 a & $1605 \mathrm{ab}$ & 43.35 & 43.64 & 37.20 \\
\hline Soil amendments with poultry refuse & $1365 \mathrm{~b}$ & $1492 \mathrm{~b}$ & $1524 \mathrm{~b}$ & 30.70 & 36.19 & 33.85 \\
\hline Poultry refuse + Seed treatment with Provax & $1663 \mathrm{a}$ & $1676 \mathrm{a}$ & $1705 \mathrm{a}$ & 43.11 & 43.20 & 40.88 \\
\hline LSD & 225.1 & 122.7 & 149.3 & - & - & - \\
\hline
\end{tabular}

Values in a column having same letter did not differ significantly $(\mathrm{P}=0.05)$ by LSD.

\section{Discussion}

Manure such as poultry manure and compost are organic sources of nutrients that have been shown to increase soil organic matter and improve soil quality [30]. Besides its nutrient components, compost contains high amounts of beneficial organisms that prevent and help controlling soil borne diseases. It has multiple mechanisms of disease suppression: increased plant vigor caused by nutrient availability, presence of large populations of beneficial microorganisms, and increased drainage [31]. On the other hand compost-inhabiting microorganisms such as Trichoderma spp. produce plant growth hormones and chemical compounds (e.g. siderophores, tannins, phenols) which are antagonistic to various soilborne pathogens. The soil borne plant pathogenic fungi $S$. rolfsii and Fusarium causing seedling mortality and wilt diseases of many crops and are the widespread problem for crop production. The management of these diseases by using chemicals is hardly successful. In the present study, compost with antagonistic fungi T. harzianum called Tricho-composts, poultry refuse, seed treatment with Trichoderma spore suspension and Provax $200 \mathrm{WP}$ as well as integration of poultry refuse with Provax 200 WP were evaluated against foot and root rot disease of lentil in the field during three consecutive years.
Results came out from the studies showed that integration of poultry refuse with Provax $200 \mathrm{WP}$ and soil treatment with Tricho-compost suppressed foot and root rot disease caused by soil borne pathogens $S$. rolfsii, increasing plant growth and yield of lentil. The use of organic amendments such as animal manure, green manure (the incorporation of crop residues into the soil), composts and peats has been improved soil structure and fertility [22-24], and decrease the incidence of disease caused by soil borne pathogens [25, 26]. Numerous studies have indicated that several established biocontrol agents, including strains from the genera Bacillus, Pseudomonas and Trichoderma can suppress vascular or soil borne fungal pathogens [32-35]. Fungi belonging to the genus Trichoderma and bacteria such as Pseudomonas. spp, or Bacillus subtilis, are the most promising biocontrol agents [35]. On the one hand, they stimulate plant growth, while on the other they eliminate plant pathogens by their unique antimicrobial activities, including the production of antibiotics and toxins to compete with pathogenic organisms [36]. Uzun [37] and Younis [38] also reported that Trichoderma isolates potentially reduced the disease caused by phtyopathogenic fungi such as $R$. solani, $F$. oxysporum and $S$. rolfsii.

Combination of different methods of pest control is at the heart of integrated pest management, and may result in 
either additive or synergistic effect. The expected benefit of this strategy is improved and sustainable control of pests and diseases. The goal of IPM methods is to employ measures that are more efficient, healthier, and more environmentally friendly in the long run, and to reduce the amount of pesticides used [39]. The results from the present study clearly indicated that integration of poultry refuse with chemical fungicide Provax $200 \mathrm{WP}$ or Tricho-compost having biological control agent $T$. harzianum provided effective protection measure against seedling diseases of lentil and also caused plant growth promotion with higher grain yield of lentil. The use of biocontrol agents such as Trichoderma spp and organic soil amendment in combination with other control methods, e.g. chemical fungicides, steam disinfection and soil heating or solarization has provided an effective control of soil borne pathogens and have the potential to improve soil properties, plant health and yield [40-43]. Several workers also reported that the antagonistic activity of different Trichoderma isolates against various phtyopathogenic fungi such as $R$. solani, $F$. oxysporum and $S$. rolfsii and enhanced plant growth parameter such as shoot height, root length, and shoot weight [44-49]. Ristaino [50] also reported that organic soil amendments are effective against soil borne pathogen and enhanced the yield of the crop.

Therefore, it may be concluded that integration of poultry manure as a soil amendment with chemical fungicide Provax $200 \mathrm{WP}$ as a seed treatment or soil amendment with Trichocomposts (compost having biological control agent $T$. harzianum) is the best treatment for management of seedling disease and increasing plant growth and yield of lentil.

\section{Conclusion}

Seedling disease of lentil caused by soil borne pathogen Sclerotium rolfsii is one of the most common and prevalent disease which affects seed germination and seedling survival as well as yield in the field. In this study the formulated biocontrol agent Trichoderma harzianum based Tricho-compost, Trichoderma spore suspension called Trichoderma inocula, organic soil amendment poultry refuse and chemical fungicide Provax 200 WP were tested against the disease in the field. The findings of the present investigations revealed that integration of poultry refuse as a soil amendment with chemical fungicide Provax $200 \mathrm{WP}$ as a seed treatment or soil amendment with the formulated T. harzianum based Tricho-compost is the best treatment for management of seedling disease and increasing yield of lentil under $S$. rolfsii inoculated field experiments in Bangladesh. Soil amendment with only poultry refuses or seed treatment with chemical fungicide also better treatment against the disease and also increasing yield of lentil.

\section{Acknowledgements}

The authors thankfully acknowledged Bangladesh Agricultural Research Institute, Gazipur to provide financial support and logistic support. Special thanks to Dr. M. A. Rahman, Ex-Chief Scientific Officer and Head, Plant Pathology Division, BARI for his fruitful discussions. Thanks go to Mr. Md. Abdur Razzak and Mr. Zamil Akter (Scientific Assistant) for their sincere assistance in this research work.

\section{Conflict of Interest Statement}

The authors whose name is listed immediately below certify that they have NO affiliation with or involvement in any organization or entity with any financial interest (such as honoraria; educational grants; participation in speakers' bureaus; membership, employment, consultancies, stock ownership, or other equity interest; and expert testimony or patent-licensing arrangements), or non-financial interest (such as personal or professional relationships, affiliations, knowledge or beliefs) in the subject matter or materials discussed in this manuscript.

\section{References}

[1] BBS. 2011. Bangladesh Bureau of Statistics. Ministry of Planning. Dhaka, Bangladesh. 126.

[2] Sattar MA Podder AR, Chandra MC., Rahman M. 1996. The most promising BNF technology for green legume production in Bangladesh. BNF Association, Dhaka, BD. 28, Nov, 1994 pp. 15-20.

[3] Hossain I, Khan MAI, Podder AK. 1999. Seed treatment with Rhizobium in controlling Fusarium oxysporum and Sclerotium rolfsii for biomass and seed production of lentil (Lens cuilinaris M.). Bangladesh J. Environ. Sci. 5: 61-64.

[4] Fakir GA. 1983. Status of research on pulse disease at the BAU, Department of Plant Pathology BAU, Mymensingh.

[5] Begum F. 2003. Integrated control of seedling mortality of lentil caused by Sclerotium rolfsii. MS thesis submitted to the Department of Plant Pathology, Bangladesh Sheikh Mujibur Rahman Agricultural University, Gazipur, Bangladesh.

[6] Ahmed HU. 1985. Disease problems of pulse and oil seed crops in Bangladesh. A paper presented in the 1st National Phytopathology. Conf. BARI Gazipur.

[7] Gerhardson B. 2002. Biological substitutes for pesticides. Trends Biotechnol. 20: 338-343.

[8] Larkin RP, Roberts D., Gracia-Garza JA. 1998. Biological control of fungal diseases. In Fungicidal activity, chemical and biological approaches. (pp 141-191). New York, NY: Wiley.

[9] Kirkegaard JA, Sarwar M, Wong PTW, Mead A, Howe G, Newell M. 2000. Field studies on the biofumigation of take-all by Brassica break crops. Australian Journal of Agricultural Research, 51 (4), 445-456. doi: 10.1071/AR99106.

[10] Ryckeboer J. 2001. Biowaste and yard waste composts: Microbiological and hygienic aspects: Suppressiveness to plant diseases. Katholieke Universiteit Leuven, Faculteit Landbouwkundige en Toegepaste, Biologische Wetenschappen, Laboratorium voor Fytopathologie en Plantenbescherming. 
[11] Bailey KL, Lazarovits G. 2003. Suppressing soilborne diseases with residue management and organic amendments. Soil and Tillage Research, 72 (2), 169-180.

[12] Louws FJ, Rivard CL, Kubota C. 2010. Grafting fruiting vegetables to manage soilborne pathogens, foliar pathogens, arthropods and weeds. Scientia Horticulturae, 127 (2), 127-146.

[13] Harman GE. 2011. Multifunctional fungal plant symbionts: new tools to enhance plant growth and Productivity. New Phytologist Commentry, Forum (3): 647-649.

[14] Singh BN, Singh A, Singh SP, Singh HB. 2011. Trichoderma harzianum-mediated reprogramming of oxidative stress response in root apoplast of sunflower enhances defense against Rhizoctonia solani. European Journal of Plant Pathology 131 (1): 121-134.

[15] Benitez T, Rincon AM, Limon MC, Codon AC. 2004. Biocontrol mechanisms of Trichodermastrains, a review article. Intl. Microbiol. 7: 249-260.

[16] Harman GE. 2006. Overview of mechanisms and uses of Trichoderma spp. Phytopathology, 96: 190-194.

[17] Shalini KP, Lata Narayan, Kotasthane AS. 2006. Genetic relatedness among Trichoderma isolates inhibiting a pathogenic fungi Rhizoctonia solani, African Journal of Biotechnology, 5 (8): 580-584.

[18] Das BC, Roy SK, Bora LC. 1997. Mass multiplication of Trichoderma species on different media. J. Agril. Sci. Society of North East India. 10 (1): 95-100.

[19] Shamsuzzaman, Islam SMA, Hossain I. 2003. Trichoderma culture and germination of sweet gourd seed. Bangladesh J. Seed Sci. and Tech. 7 (1 and 2): 91-95.

[20] Rettinassababady C, Ramadoss N. 2000. Effect of different substrates on the growth and sporulation of Trichoderma viride native isolates. Agril. Sci. Digest. 20 (3): 150-152.

[21] Cotxarrera L, Trillas-Gay MI, Steinberg C, Alabouvette C. 2002. Use of sewage sludge compost and Trichoderma asperellum isolates to suppress Fusarium wilt of tomato. Soil Biology and Biochemistry, 34, 467-476.

[22] Magid J, Henriksen O, Thorup-Kristensen K, Mueller T. 2001. Disproportionately high $\mathrm{N}$-mineralisation rates from green manures at low temperatures - implications for modelling and management in cool temperate agro-ecosystems. Plant and Soil 228: 73-82.

[23] Conklin AE, Erich MS, Liebman M, Lambert D, Gallandt ER, Halteman WA. 2002. Effects of red clover (Trifolium pratense) green manure and compost soil amendments on wild mustard (Brassica kaber) growth and incidence of disease. Plant and Soil 238: 245-256.

[24] Cavigelli MA, Thien SJ. 2003. Phosphorus bioavailability following incorporation of green manure crops. Soil Science Society American Journal 67: 1186-1194.

[25] Litterick AM, Harrier L, Wallace P, Watson CA, Wood M. 2004. The role of uncomposted materials, composts, manures, and compost extracts in reducing pest and disease incidence and severity in sustainable temperate agricultural and horticultural crop production: A review. Critical Reviews in Plant Sciences 23: 453-479.

[26] Noble R, Coventry E. 2005. Suppression of soil-borne plant diseases with composts: a review. Biocontrol Science and Technology 15: 3-20.

[27] Baxter AP, Rong IH, Roux C, Van der Linde EJ. 1999. Collecting and Preserving Fungi-A Manual for Mycology. Plant Protection Research Institute. Private Bag X134, Pretoria, 0001 South Africa.

[28] Barnett HL, Hunter BB. 1972. Illustrated Genera of Imperfect Fungi. 3rd Ed. Burges Co., Minneapolis, USA.

[29] Booth C. 1971. The Genus Fusarium. Commonwealth Mycology Institute Kew, Survey, England.

[30] Wright RJ., (Ed.) 1998. Agricultural uses of municipal, animal, and industrial byproducts. USDA. Agricultural Research Service, Conservation Research Report, (44). Retrieved from http://agrienvarchive.ca/bioenergy/download/ag_use_ars.pdf

[31] Mehta CM, Palni U, Franke-Whittle IH, Sharma AK. 2014. Compost: Its role, mechanism and impact on reducing soilborne plant diseases. Waste Management, 34 (3), 607-22. pmid 24373678.

[32] Ramette A, Frapolli M, Defago G, Moenne-Loccoz Y. 2003. Phylogeny of $\mathrm{HCN}$ synthase-encoding henBC genes in biocontrol fluorescent pseudomonads and its relationship with host plant species and $\mathrm{HCN}$ synthesis ability. Molecular Plant-Microbe Interactions, 16 (6), 525-35. pmid: 12795378.

[33] Berg G, Kurze S, Buchner A, Wellington EM, Smalla K. 2000. Successful strategy for the selection of new strawberryassociated rhizobacteria antagonistic to Verticillium wilt. Canadian Journal of Microbiology, 46 (12), 1128-37. pmid: 11142403.

[34] Mavrodi OV, Walter N, Elateek S, Taylor CG, Okubara PA. 2012. Suppression of Rhizoctonia and Pythium root rot of wheat by new strains of Pseudomonas. Biological Control, 62 (2), 93-102.

[35] Bhattacharjee R, Dey U. 2014. An overview of fungal and bacterial biopesticides to control plant pathogens/diseases. African Journal of Microbiology Research, 8 (17), 1749-1762. doi 10.5897/AJMR2013.6356.

[36] Mukry SN, Ahmad A, Khan SA. 2010. Screening and partial characterization of hemolysins from Bacillus sp.: Strain S128 \& S144 are hemolysin B (HBL) producers. Pakistan Journal of Botany, 42 (1), 463-472.

[37] Uzun I. 2004. Use of spent mushroom compost in sustainable fruit production. Journal of Fruit and Ornamental Plant Research. 12: 157-165.

[38] Younis NA. 2005. Mycoparasitism of Trichoderma harzianum and Trichoderma longibrachiatum on Fusarium oxysporum f.sp. phaseoli the causal of bean wilt disease. Bull. Faculty Agric. Cairo Univ. 56: 201-219.

[39] Katan J. 1999. The methyl bromide issue: Problems and potential solutions. Journal of Plant Pathology, 81, 153-159. doi 10.4454/jpp.v81i3.1071.

[40] Omar I, O'neill TM, Rossall S. 2006. Biological control of fusarium crown and root rot of tomato with antagonistic bacteria and integrated control when combined with the fungicide carbendazim. Plant Pathology, 55 (1), 92-99. doi: 10.1111/j.1365-3059.2005.01315.x. 
[41] Klein E, Katan J, Austerweil M, Gamliel A. 2007. Controlled laboratory system to study soil solarization and organic amendment effects on plant pathogens. Phytopathology, 97 (11), 1476-1483. pmid: 18943518.

[42] Gamliel A, Katan J. 2009. Control of plant disease through soil solarization. In D. Walters (Ed.), Disease Control in Crops. (pp 196-220). Edinburgh, UK: Wiley-Blackwell Publishing Ltd.

[43] Slusarski C, Ciesielska J, Malusa E, Meszka B, Sobiczewski P. 2012. Metam sodium, metam potassium and dazomet. In Sustainable use of chemical fumigants for the control of soilborne pathogens in the horticultural sector. Skierniewice, Poland: Research Insititute of Horticulture.

[44] Deshmukh PP, Raut JG. 1992. Antagonism by Trichoderma spp. on five plant pathogenic fungi. New Agriculturist. 3 (2): 127-130.

[45] Xu T, Zhong JP, Li DB. 1993. Antagonism of T. harzianum T82 and Trichoderma species NF9 against soil and seed borne pathogens. Acta. Phytopathol. Ca. Scinica, 23 (1) 63-67.
[46] Askew DJ, Laing MD. 1994. The in-vitro screening of Trichoderma isolates for antagonism to Rhizoctonia solani and an evaluation of different environmental sites of Trichoderma as sources of aggressive strains. Plant and Soil 159 (2): 227281.

[47] Hossain I, Shamsuzzaman SM. 2003. Developing Trichoderma based bio-fungicide using agro-waste. BAU Res. Prog. 14: 49-50.

[48] Hossain I., Naznin M. H. A. 2005. BAU biofungicide in controlling seedling disease of some summer vegetables. BAU Res. Progr. 15: 32-35.

[49] Shaban WI, El-Bramawy MA. 2011. Impact of dual inoculation with Rhizobium and Trichoderma on damping off, root rot diseases and plant growth parameters of some legumes field crop under greenhouse conditions. Int. Res. J. Agric. Sci. Soil Sci. 1: 98-108.

[50] Ristaino JB. 2002. Effect of synthetic and organic soil fertility amendments on southern blight, soil microbial communities, and yield of processing tomatoes. Phytopathology 92: 181-189. 